Page $\mid 1$

\title{
The Little Door to Hell - Torture and the Ticking Bomb Argument
}

by Filip Spagnoli (draft - please do not use without permission)

Brussels, March 26, 2009, revision: August 22, 2011 


\section{Table of Contents}

0. Introduction

1. What is torture?

2. What is the ticking bomb argument?

3. Assumptions of the ticking bomb argument

3.1. Assumption 1: A real-life case

3.2. Assumption 2: Knowledge and knowledge about knowledge

3.3. Assumption 3: It works

3.4. Assumption 4: No alternative

3.5. Assumption 5: Exceptional

3.6. Assumption 6: The Greater Good

4. Conclusion

References

The Little Door to Hell - Torture and the Ticking Bomb Argument | Filip Spagnoli 
"We cannot torture because of who we are".

Michael Ignatieff 1

"If torture is the only means of obtaining the information necessary to prevent the detonation of a nuclear bomb in Times Square, torture should be used - and will be used - to obtain the information. ... no one who doubts that this is the case should be in a position of responsibility."

Richard Posner ${ }^{2}$

"During numerous public appearances since September 11, 2001, I have asked audiences for a show of hands as to how many would support the use of nonlethal torture in a ticking-bomb case. Virtually every hand is raised."

Alan Dershowitz ${ }^{3}$

\section{Introduction}

The most astonishing by-product of the events of 9-11 is undoubtedly the renewed legitimacy, in the eyes of many, of some forms of torture. Since many centuries, the most brutal dictators have felt the need to lie and deceive about their torture practices, and now we have political and intellectual leaders of the free world openly arguing in favor of the use of torture in certain cases. The most commonly cited of these cases is the one described in the so-called "ticking bomb argument" (henceforth TBA).

The kind of torture that is supposedly justified by this argument can be characterized as benevolent torture, well-intentioned torture, or even moral torture because it is different from torture as it is commonly used by certain oppressive or authoritarian governments. "Ticking bomb torture" is not a method of terrorizing and subjugating a population, and neither is it a form of criminal punishment or a means of establishing innocence or guilt. On the contrary, its declared purpose is to protect the population and to avoid a terrorist attack on civilian targets. It is benevolent tor-

\footnotetext{
${ }^{1}$ In Rebecca Evans (2007), The Ethics of Torture, in Human Rights \& Human Welfare, Vol. 7.

2 In The New Republic, September 2002.

${ }^{3}$ Alan Dershowitz (2002), Why Terrorism Works, Yale University Press, New Haven \& London.
} 
ture because its objective is not fear or punishment, but safety and security. It is moral torture because reluctance to engage in it would endanger the lives of innocent civilians, and would therefore be immoral. "A society that elects to favor the interests of wrongdoers over those of the innocent, when a choice must be made between the two, is in need of serious ethical rewiring". 4

Proponents of the TBA readily agree that they discuss an exceptional case which is unrepresentative of torture in general - most real cases of torture have absolutely nothing to do with the example given in the TBA or fail to conform to the hypotheses present in the TBA - and which in no way justifies torture that has other, and less benevolent purposes. Yet they believe that this exceptional nature of the case does not render it insignificant or irrelevant. In the setting of a "war on terrorism", it can be extremely important to agree on the soundness of the TBA because no matter how exceptional the case may be, when it occurs it has important consequences. A clear agreement on the TBA is necessary in order to save many lives in exceptional cases.

I will argue in this paper that the TBA is fundamentally flawed because it is based on a number of untenable assumptions. Moreover, I argue that the TBA, when thought through until its logical conclusions, ends up condoning torture of a much less exceptional and benevolent nature than the torture it started with. In other words, the TBA proves too much. It would not only put us on a "slippery slope" towards ever increasing levels of torture, but also destroy our democracy and freedom. It is, in the words of the title of this paper, the little door to hell. The TBA tries to force a small opening into an area of human activity that is shielded by a very strong, and perhaps even absolute moral $^{5}$ and legal ${ }^{6}$ taboo, and then finds that it has allowed this activity to take over civilization.

\section{What is torture?}

I'll first present a short, operational definition of torture. ${ }^{7}$ Torture is

- The intentional and non-accidental infliction of severe physical - and in some cases mental - pain or suffering 8 by one person on another, non-

\footnotetext{
${ }^{4}$ Mirko Bagaric, in The Age, May 17, 2005, http://www.theage.com.au/news/Opinion/A-case-fortorture/2005/05/16/1116095904947.html.

5 Jeremy Waldron, What Are Moral Absolutes Like, Lecture presented at the Annual Lecture for the Harvard Philosophy Club, Cambridge, Massachusetts, April 2011, http://papers.ssrn.com/sol3/papers.cfm?abstract_id=1906850

${ }^{6}$ See the United Nations Convention Against Torture: "No exceptional circumstances whatsoever, whether a state of war or a threat of war, internal political in stability or any other public emergency, may be invoked as a justification of torture", (article 2), http://www2.ohchr.org/english/law/cat.htm.

${ }^{7}$ Based loosely on the Stanford Encyclopedia of Philosophy lemma on torture, http://plato.stanford.edu/entries/torture/.
} 
consenting and defenseless person who may or may not be guilty of a crime.

- While assuming complete control over the victim's body and autonomy.

- With the purpose of

- extracting information (forward-looking) or a confession (backward-looking $)^{9}$

- and/or punishing or degrading the victim

- and/or coercing the victim to act in a certain way or believe certain things

- and/or terrorizing, intimidating, pacifying or oppressing the victim and/or the wider society.

This definition is compatible with, although somewhat wider than, the definition offered in the United Nations Convention Against Torture:

"Torture is any act by which severe pain or suffering, whether physical or mental, is intentionally inflicted on a male or female person for such purposes as obtaining from him, or a third person, information or a confession, punishing him for an act he or a third person has committed or is suspected of having committed, or intimidating or coercing him or a third person, or for any reason based on discrimination of any kind, when such pain or suffering is inflicted by or at the instigation of or with the consent or acquiescence of a public official or other person acting in an official capacity. It does not include pain or suffering arising only from, inherent in, or incidental to, lawful sanctions". ${ }^{10}$

These definitions exclude, at first sight, acts of self-defense, masochism or other types of consensual violence, violent acts between combatants in the course of war, "collateral damage" or accidental injuries to civilians in the course of war, some forms of atomic warfare, some forms of corporal punishment and possible other actions as well. Although these actions are not, according to the definitions given above, cases of torture, they may be morally wrong, and perhaps even more so than torture. However, none of this is uncontroversial, and I accept that the definition of torture as described here can be criticized. Nevertheless, I would ask the reader to accept this definition on face value and temporarily, for the duration of my argument. The purpose here is simply to offer a workable definition, not to enter into a philosophical argument on the nature of torture. Such an argument is obviously necessary - especially given the recent attempts, for instance by the Bush Administration, to narrow down the concept of torture in such a way that many acts normally considered to be torture, would become admissible ${ }^{11}$ - but I consciously sidestep it here because it would distract from the main objective of this paper.

\footnotetext{
${ }^{8}$ An example of mental suffering is a mock execution.

${ }^{9}$ See David Luban (2005), Liberalism, Torture, and the Ticking Bomb, in Virginia Law Review, Vol. 91, p. 1436, http://www.virginialawreview.org/content/pdfs/91/1425.pdf.

10 http://www2.ohchr.org/english/law/cat.htm.

11 Take for instance John Yoo's and the Justice Department's infamous definition of torture: "Physical pain amounting to torture must be equivalent in intensity to the pain accompanying serious physical injury, such
} 


\title{
2. What is the ticking bomb argument?
}

Page $\mid 6$

\begin{abstract}
The TBA has been put forward and defended by many writers and politicians, ${ }^{12}$ hence there are many versions. However, they all start with a description of a very particular type of terrorist attack: a ticking bomb has been hidden in a densely populated area and will soon kill thousands or millions if not disarmed, and the authorities have captured a terrorist who has either hidden the bomb himself or knows where it has been hidden. One can replace the "ticking bomb" with another and similar type of deadly devise without changing the nature of the TBA. (The "ticking bomb" is in fact a "pars pro toto", encompassing cases which do not necessarily involve an actual ticking bomb but which are nevertheless similar with respect to their circumstances and consequences).
\end{abstract}

The problem faced by the authorities is that the captured person does not want to reveal the whereabouts of the bomb, but will do so under torture. There is no other or alternative way to extract this information. Are we not morally allowed to use torture in order to get the information and save numerous lives? Or, a somewhat stronger claim: are we not morally forced to torture given the enormous benefits for large numbers of people compared to the limited costs for the tortured individual? "Given the choice between inflicting a relatively small level of harm on a wrongdoer and saving an innocent person, it is verging on moral indecency to prefer the interests of the wrongdoer". 13

This stylized description of the TBA brings out the claim regarding the moral and benevolent nature of the kind of torture that is defended here. Torture, according to the TBA, is morally justified in such cases, and perhaps even also morally necessary given the absence of alternatives. A refusal to torture would be immoral because it would necessarily lead to bloodshed. The government official who willfully declines to use the only available option to stop a terrorist attack, is as guilty and immoral as the terrorist.

The moral nature of torture is not incompatible with the belief that torture is morally wrong. Most proponents of the TBA agree that torture is morally wrong, but argue that it is a lesser evil in some circumstances, and justify it on these grounds. They commonly engage in some form of consequentialist or utilitarian moral reasoning. For most consequentialists, a lesser of two evils is the morally right ac-

\footnotetext{
as organ failure, impairment of bodily function, or even death. For purely mental pain or suffering to amount to torture (under U.S. law), it must result in significant psychological harm of significant duration, e.g., lasting for months or even years", http://berkeley.edu/news/media/releases/2005/01/05_johnyoo.shtml. See also Rebecca Evans (2007), The Ethics of Torture, in Human Rights \& Human Welfare, Vol. 7.

12 Inter alia Charles Krauthammer, Mirko Bagaric, Philip Bobbitt, Richard Posner, Alan Dershowitz and Fritz Allhoff.

13 Mirko Bagaric, in The Age, May 17, 2005, http://www.theage.com.au/news/Opinion/A-case-fortorture/2005/05/16/1116095904947.html.
} 
tion. ${ }^{14}$ An "evil" or immoral action is morally right and morally necessary if it is able to stop or undo another "evil" or immoral action that causes or would cause more harm. Any action is morally right, according to consequentialism, if it maximizes total aggregate happiness (or utility), and minimizes total aggregate harm. ${ }^{15}$ The consequentialism of the TBA rejects the absolute prohibition against torture typical of the deontologist school of moral thought. ${ }^{16}$

The main assumptions of the ticking bomb case, as it is described in most versions of the TBA, are:

- A terrorist attack is being planned in a known location. It is also known that the attack is about to be carried out in the very near future. The "ticking" element of the TBA conveys a sense of great urgency. This means that alternatives not involving torture - such as evacuation - are not available. (Again, no actually "ticking" bomb is required for the TBA to work - a similar device or procedure creating the same urgency will do the trick).

- The terrorist who has hidden the bomb, or one of his accomplices who knows where it is hidden, has been captured by the authorities of the country/city/etc. that will be the target of the attack.

- The government agents who captured the terrorist/accomplice know the location and the imminence of the attack, but they also know that the captured person has information which, if extracted, can prevent the attack.

- The information cannot be extracted from the terrorist/accomplice without torture.

Below I will expand and criticize some of these assumptions.

\section{Assumptions of the ticking bomb argument}

The TBA works on the basis of a number of explicit and implicit assumptions. If it can be argued convincingly that these assumptions are untenable, either in themselves or because they result in unwanted consequences, then the TBA will lose much if not all of its strength.

\subsection{Assumption 1: A real-life case}

A first assumption of the TBA is that the ticking bomb scenario describes a case that is a real possibility and that governments may one day have to deal with (or have dealt with already). In other words, it is not just a thought experiment, like

\footnotetext{
14 Antony Lamb (2008), Review of Bob Brecher (2007), Torture and the Ticking Bomb, Blackwell Publishing, Oxford, in Philosophical Frontiers, Vol. 3, Issue 2.

15 Allhoff, Fritz (2005), A Defense of Torture: Separation of Cases, Ticking Time-bombs and Moral Justification, in International Journal of Applied Philosophy, 19:2, p. 248.

16 Brecher is an example of a deontologist, although he chooses to attack the TBA on utilitarian grounds.
} 
Schrödinger's cat or Maxwell's demon. Indeed, proponents of the TBA argue that the ongoing "war on terror" makes the scenario all the more realistic.

Although we can't categorically state that the scenario will never occur in real life, the probability that it will is extremely low. This is because of the very demanding nature of the assumptions of the scenario. For example, law enforcement officers or military and intelligence personnel usually do not arrest terrorists or accomplices before the terrorist act takes place (usually they make the arrests afterwards, and sometimes they do not even manage to do that). And even when they make an arrest before the attack, it is unlikely that they have enough information to know that they have captured someone who knows the whereabouts of a bomb that is about to go off.

So the case is extremely exceptional at best. However, it is not an impossible case. I agree, therefore, with the proponents of the TBA that this first assumption is correct. A ticking bomb case can present itself to the authorities of a country: it may be possible in some instances to arrest a terrorist or an accomplice just before the terrorist act takes place, and one may, at that time, know that the attack will take place and that the person on custody has relevant information.

The exceptional nature of the case is confirmed by the fact that there are as yet no historical examples. Some cases that are claimed to be "ticking bomb cases" - such as the torture of Abdul Hakim Murad - are in fact, after closer examination, none of the kind. Murad only gave away his information after a month of torture, and it came as a surprise. He was tortured not because of an imminent threat. There was no such threat, and the torturers did not act on the assumption that there was.

"In 1995, the police in the Philippines tortured Abdul Hakim Murad after finding a bomb-making factory in his apartment in Manila. They broke his ribs, burned him with cigarettes, forced water down his throat, then threatened to turn him over to the Israelis. Finally, from this withered and broken man came secrets of a terror plot to blow up 11 airliners, crash another into the headquarters of the Central Intelligence Agency and to assassinate the pope. ... it took more than a month to break Mr. Murad and extract information - a delay that would have made it impossible to head off an imminent threat". ${ }^{17}$

\subsection{Assumption 2: Knowledge and knowledge about knowledge}

So we can agree with the proponents of the TBA that a ticking bomb case, as described in the TBA, can indeed occur in real life, and that one is, in exceptional cases, able to arrest a terrorist or accomplice just before the terrorist act takes place, and that one knows that the attack will take place. For the ticking bomb argument to be valid, however, we need a further assumption. Torture does not seem to

\footnotetext{
${ }^{17}$ Michael Slackman, What's Wrong With Torturing A Qaeda Higher-Up?, in The New York Times, Sunday, May 16, 2004.
} 
be justified by the simple fact that we know that a bomb is about to go off, and that we have arrested someone who we believe, based on good reasons, is involved in the attack. We have to be positively sure that the captured terrorist or accomplice does indeed have the information that is required for us to stop the attack or explosion to take place.

This assumption reduces the probability of a ticking bomb case. Most of the time, we are not sure that a captured terrorist is someone who knows where the ticking bomb is hidden. All we may have is a good guess. And even if the captured terrorist told us that he knows, he may be a fantasist.

But if we are not sure that the person under arrest has the necessary information, can we then start torturing this person in order to be sure? That would mean that we do not just torture in order to get life saving information. We torture in order to know whether this person has or does not have such information. It is obvious that in this case we may torture people who don't have information, or that we may have to torture many people before we find the right person. Hence, we may have to torture innocent people, or at least people who, although accomplices, are not justifiable objects of torture since the TBA claims that torture is justified because it is necessary to obtain life saving information. These people do not have such information, and hence their torture is not justified according to the TBA. Some other justification is required in order to be able to use torture on people who do not obviously and undoubtedly possess life saving information. This seems to fall outside the TBA, an argument which is therefore at best incomplete. Because of this imperfection in the TBA, its proponents will be tempted to expand the TBA in order to save it, and to allow "second degree torture", torture not only of the terrorist who we know has information, but also of people who we suspect may have information. This is the first but not the last time the TBA expands the field of justified torture.

One could accept the validity of the TBA if this expansion does not (have to) take place - and if the other assumptions described below are correct - but the price to pay would most likely be futility. We would be accepting an argument that has no practical use because it is about a case that is extremely exceptional. Indeed, real life cases will rarely if ever have to following characteristics:

- we have captured a terrorist just before an imminent attack

- we know that there is an attack imminent

- and we know for certain that the captured terrorist has vital information that will allow us to stop the attack.

Especially the latter characteristic is very improbable, which gives us the choice of either not torturing anybody, or torturing a possibly numerous set of people in order to pinpoint the person with the vital information.

Proponents of the TBA are unlikely to stop here, for reasons described below (reasons which are related to the consequentialism of most of these proponents). Hence they are likely to accept the expansion of torture, from the single terrorist having vital information about the attack, to a wider range of persons who, we suspect, may have such information. This expansion is not only a spatial one. It also means 
moving torture at a higher level of cruelty. Torturing people in order to find out if they have information is likely to be the worst kind of torture: since many of them do not know anything, they will be subject to the longest and deepest forms of torture. ${ }^{18}$

\subsection{Assumption 3: It works}

However, the TBA still needs a further assumption, namely that torture is an efficient tool for extracting reliable information. Even if we grant assumption 2 - we have captured someone who knows about the bomb, and we know that he knows that does not by itself justify torture.

There's widespread evidence that torture does not allow the extraction of reliable information. ${ }^{19}$ And this also corresponds to intuition: people who are tortured say anything in order to make it stop. When they are innocent and don't know anything, they will send the torturers off in all directions at a time when focused and urgent action is needed. And when the torturers have identified the correct person, i.e. the person having life saving information, they will torture someone who knows that the attack is imminent and who is therefore highly motivated to endure what he or she knows to be a relatively short "session". This person is probably also trained to endure torture.

The supposed efficiency of torture is also undermined in other ways, for instance by the likelihood that the terrorist, knowing that the attack is imminent and that time is of the essence, will deliberately give false information so as to misdirect the torturers long enough for the bomb to go off. The torturers have to engage in this kind of wild goose chases because they don't have the time to verify the story through prolonged "verification torture" (torture that is intended to test a story extracted by previous torture). They have to go and check that the bomb is indeed where the terrorist told them to find it. ${ }^{20}$

If torturing the terrorist does not make him or her speak, the TBA must, according to its own logic, also justify torturing the terrorist's family, children and friends (a kind of indirect torture aimed at "convincing" the terrorist to give information). If torturing him or her is insufficient, then further options are equally justifiable. The cost-benefit analysis on which the ticking bomb argument is based justifies torturing the family. The guilt or innocence of the family, or of anybody else who is tortured, is irrelevant. What counts is that the cost of torture does not outweigh the

\footnotetext{
18 See Defusing the Ticking Bomb Scenario, paper by the Association for the Prevention of Torture, (2007), p. 7, http://www.apt.ch/content/view/109/lang,en/.

${ }^{19}$ See for instance Michael Slackman, What's Wrong With Torturing A Qaeda Higher-Up?, in The New York Times, Sunday, May 16, 2004, or Rebecca Evans (2007), The Ethics of Torture, in Human Rights \& Human Welfare, Vol. 7, p. 57.

20 See Defusing the Ticking Bomb Scenario, paper by the Association for the Prevention of Torture, (2007), p. 8, and also Clive Coleman, Why ticking-bomb torture stinks, http://www.timesonline.co.uk/tol/comment/columnists/guest_contributors/article785050.ece.
} 
good it does, i.e. the number of lives it saves. Of course, we don't torture one terrorist or one terrorist's family in order to save one other person or family, but the gains of torture are stipulated as being extremely high in the TBA. Torturing the family of the terrorist is, like torturing the terrorist himself, a lesser evil compared to the harm resulting from our failure to stop the attack. After all, the torture of the terrorist himself is not justified by his guilt or complicity, but simply by the benefits that result from the information that is extracted through torture. Hence, torturing innocent family members is no objection if it produces a greater good (see also below).

This is a second expansion of torture warranted by the TBA. However, if we add this expansion to the expansion described in the previous paragraph, we may be talking about a relatively large group of torture victims, and the utilitarian calculus may no longer be as clear cut as it seemed in the beginning, forcing the proponent of the TBA to increase the number of lives saved by torture.

Ultimately, the proponents of the TBA have to say how far they are willing to go. If torturing one person doesn't work, how many people can be tortured in order to save how many lives? 1 for 1.000 lives? 1 for 2 lives? Or just always one less than the number of lives saved by torture? The risk of a slippery slope leading to a wide application of torture is evident.

The proponents of the TBA could of course claim that we are pushing the argument too far, and that such borderline cases are even more exceptional than ticking bomb cases in general. They could argue that things are clear when we go into the really big numbers of people saved by torturing a few individuals, and that the TBA is about those cases only. Torturing even a few people in order to safe a thousand or a million is a "no-brainer" (in the words of former Vice-President Cheney ${ }^{21}$ ).

Again, this defense of the TBA risks a collapse into futility. The reality is that most terrorist attacks do not kill millions or even thousands. A few dozen is a more realistic number. And, at the same time, the number of perpetrators is usually much higher than the single "super-villain" depicted in the TBA. Hence the risk that the "torture candidates" - including those suspected of having knowledge as well as friends and family - outnumber the number of likely victims and that the costbenefit analysis typical of the TBA doesn't hold water. Again, one is allowed to wonder if the TBA has any relation to reality.

In a certain sense, the fact that real-life terrorism usually kills only a small number of people limits the risk of the slippery slope: if terrorists usually don't kill large numbers of people, then torture isn't justified under TBA - the utilitarian calculus of the TBA proponents demands that the benefits resulting from torture far outweigh the harm done by torture. I don't know of any TBA proponent who justifies torture if it produces only a small overall benefit. On the other hand, we now see that the element of urgency and the imminent character of the attack have been sidelined by the TBA. What matters is not the timeframe but the balance of harm. Therefore, the cases where torture is justified in the philosophy of the TBA proponents are no longer limited to ticking bomb cases but cover many more terrorist attacks, namely

\footnotetext{
21 in http://www.washingtonpost.com/wp-dyn/content/article/2006/10/26/AR2006102601521.html.
} 
all those attacks where the possible harm of the attack is much larger than the harm inflicted by torture. ${ }^{22}$

\subsection{Assumption 4: No alternative}

Again, let us accept all the above assumptions, for the sake of argument. Even if

- there are and will be real cases of terrorist attacks resembling the description of the TBA,

- there are no knowledge or information problems,

- and torture is an efficient tool for extracting information,

then there is yet another assumption implicit in the TBA: one of the supposedly strong points of the ticking bomb argument is the lack of an alternative to torture. There seems to be nothing else one can do in the given case (remember that one of the characteristics of the case is urgency). Even if we're not sure that torture works, that we are torturing the right person, that this person will not deliberately waste our time, and that we run the risk of having to torture innocent people, what else can we do? Maybe we are torturing the right person and maybe he will help.

However, this supposed lack of an alternative hinges on some dubious assumptions regarding the timing:

"On the one hand, to represent some type of ticking bomb scenario, the timing of attack must be far enough in the future that there is a realistic chance of doing something to stop it. On the other hand, if it is so far off in the future that the loss of life can be prevented in some other way (evacuation, for instance) then the supposed "need" for torture simply disappears. Furthermore, the more time until the attack, the greater the chance that humane interrogation methods will produce results". ${ }^{23}$

\subsection{Assumption 5: Exceptional}

Given the urgency in the example of the ticking bomb, and given the fact that terrorists are often trained to withstand torture, a free society would have to "maintain a professional class of torturers, and to equip them with continuously-updated torture techniques and equipment. Grave dangers to democracy and to individual freedoms would be posed by an institutionalized professional "torture squad"." 24

Such a highly trained and continuously available torture squad would be necessary to inflict torture that is likely to succeed in extracting the information on a reliable

\footnotetext{
22 Rebecca Evans (2007), The Ethics of Torture, in Human Rights \& Human Welfare, Vol. 7, p. 58.

23 Defusing the Ticking Bomb Scenario, paper by the Association for the Prevention of Torture, (2007), p. 6, http://www.apt.ch/content/view/109/lang,en/.

24 ibidem, p. 9.
} 
basis and within an extremely short time frame, that inflicts levels of pain sufficient to procure the victim's compliance but insufficient to kill or render incapable of communication. Amateur thugs will not suffice.

This is the institutionalization of torture. It is difficult to see how a free society could survive the presence of such a squad. It would infect the entire society to know that there are people among us who torture for a living. The squad members themselves will most likely fail to remain well-intentioned, and the mere existence of such a squad corrupts morality in a society. It's naive to think that the members of the torture squad will return to normality once their job is done and function like normal law-abiding and non-violent citizens in between emergency sessions. ${ }^{25}$ Again we see that it is highly probable that the logical conclusions resulting from the TBA will lead to an expansion of torture and perhaps even the destruction of a democracy and a free society that decides to go this way.

It's likely that only the direct harm produced by torture is included in the utilitarian calculus, and that long-term damage to freedom and democracy is excluded.

The TBA therefore results in an expansion of torture in several ways. First, the TBA's utilitarianism justifies torture of many more people than only the "captured terrorist", and its reliance on the assumption of information availability forces it to accept torture as a means to determine the fact that someone has or doesn't have information. Secondly, the TBA's utilitarianism leads to justifications of torture that go beyond the imminent and urgent cases that the TBA starts with. And thirdly, the TBA is forced to accept the institutionalization of torture, and with it the risk of normalization of torture. Ultimately, the TBA may destroy political freedom altogether.

But the expansion doesn't stop at the borders of the torturing state. If a democratic government wants to use torture, in so-called exceptional cases and for benevolent motives, then it renders torture legitimate in the eyes of other governments who worry much less about exceptions and benevolence. If the U.S. for example violates the principles it teaches, other and more repressive governments will find it easier to resist calls for change. The U.S. or other democratic states will expose themselves as hypocrites. They will be weakened in their attempts to democratize other countries and make them more respectful of human rights. Hence, torture in free societies, supposedly justified by the TBA, promotes torture elsewhere, and because of this these free societies - to the extent that they remain free - will ultimately have a much harder time to do something about some of the human rights violations that feed some of the terrorism that torture was supposed to stop. Torturing terrorists is therefore counterproductive. And this is true for another reason as well. If you use torture in order to stop terrorists, you radicalize these terrorists and you promote existing opposition to your country. Terrorists will find it easier to recruit volunteers to fight against you, to win sympathy and support among populations etc. And this will lead to more terrorism and possibly a vicious circle if this increased terrorism incites your country to allow even more torture. So much for the "exceptional" nature of torture in the TBA.

${ }^{25}$ See David Miller, The Use and Abuse of Political Violence, in Political Studies, 32 (1984), 401. 


\subsection{Assumption 6: The Greater Good}

Page $\mid 14$

A utilitarian or consequentialist could argue that the preceding arguments against the TBA rest on the false assumption that it is acceptable to risk great loss of life for the sake of a principle or a philosophical argument, no matter how persuasive. Contrary to this, he or she might say that "lost lives hurt a lot more than bent principles". ${ }^{26}$ Torturing someone who has information on the whereabouts of a ticking bomb is clearly a lesser evil than allowing the bomb to go off. Proponents of the TBA reject what they call the moral absolutism or moral perfectionism of the deontologists rejecting any type of torture under any circumstances. ${ }^{27}$ Should we "let justice be done though the heavens fall", or rather minimize a certain type of injustice even if this requires accepting some minor act of injustice of another type?

First of all, as I have shown in the previous paragraphs, it is not evident that the number of people that need to be tortured is much smaller than the possible victims of the ticking bomb. If the terrorist himself does not confess fast enough, how about torturing his family and children, or the people in his phone book? And if it is uncertain whether the captured terrorist holds vital information - as will be the case in most real-life settings - we may have to torture people in order to determine who knows what.

Secondly, this greater good thinking puts the torturers on the same footing as the terrorists. The latter also assume that they fight for a greater good and that he harm they do is small compared to the benefits this harm will produce. The similarity between torturers and terrorists is all the more striking if the torturers have convinced themselves that it is necessary to torture innocents (see assumptions 2 and 3 above). Putting ourselves on the same level as terrorists means giving up our identity to save ourselves, which really is pointless. So this is the second time we find that torture destroys the torturer (see assumption 5 above). If we remodel the utilitarian calculus: the harm done by social and political self-degeneration and selfdestruction is probably greater than the suffering caused by exceptional terrorists attacks. So even the utilitarianism of the greater good doesn't justify torture.

There's also the notion of "tainted goods": even if we don't lose ourselves through either the institutionalization of torture (assumption 5 above) or the equivalence with terrorists (assumption 6), the supposed "good" that we achieve through torture will be tainted by the methods necessary to achieve it. ${ }^{28}$ The notion, inherent in the TBA, that certain goods can be attainted by problematic means, is itself problematic. Suppose we successfully fight terrorism with torture and save our democratic

\footnotetext{
26 Mirko Bagaric, in The Age, May 17, 2005, http://www.theage.com.au/news/Opinion/A-case-fortorture/2005/05/16/1116095904947.html.

27 This deontologism is also reflected in the United Nations Convention Against Torture (see note 6 above) and in the writing of Waldron (note 5 above).

28 Jeremy Waldron (2010), Torture, Terror and Trade-offs: Philosophy for the White House, Oxford University Press
} 
society (that means, we also successfully avoided self-degeneration). Many lives are saved and our way of being has been maintained. And yet, we may believe that our success has been tainted by the immoral methods used to achieve it, and we may not be willing to enjoy this success and the goods we have if they have been secured by way of torture.

Page $\mid 15$

\section{Conclusion}

Upon reflection, the TBA seems to be no more than a thought experiment, good material for café discussions among philosophers but useless policy advice for officials having to deal with real cases. Nevertheless, the exceptional, improbable, or even hypothetical nature of the ticking bomb case does not make it irrelevant and is not a sufficient reason to dismiss it. Indeed, the TBA is often used to justify torture in general rather than the very specific kind of torture described in the TBA. When there is one case that can water down the absolute rule against torture - even if it's an entirely theoretical case - why should there not be other cases? "Even if the example I gave were entirely hypothetical, the conclusion - yes, in this case even torture is permissible - is telling because it establishes the principle: torture is not always impermissible". ${ }^{29}$ So even those who are convinced that the TBA is entirely fanciful need to address its errors in order to destroy the seeds of doubt which the TBA intends to sow.

It seems to me that the dramatic force and moral clarity and simplicity of the TBA (undoubtedly the reasons for its popularity) can be used by those who are in favor of torture as a means to open the door and make some cracks in what is still, for many, a moral absolute (similar to the prohibition of slavery and genocide). Keeping the door firmly shut requires a critical engagement with the assumptions inherent in the TBA.

The ticking bomb argument is intended to show that an absolute ban on torture is unwise and ultimately detrimental to the survival of a free society. Opponents of torture are labeled naive moral absolutists, locked up in ivory towers and unwilling to confront the darker sides of reality and isolated from the tough problems that people in the field have to deal with. By making it impossible to "deal" with these tough problems, absolutists endanger the nation. However, I have tried to show that the proponents of the TBA are the ones refusing to face reality. The moral absolutists aren't the ones who fail to protect freedom or who lack patriotism; those who want to allow torture in the ticking bomb case undermine their own goals because they endanger freedom and flirt with the destruction, not of terrorism, but of democracy. In fact, those who defend torture for the sake of combating terrorism are doing the work of the terrorists for them.

\footnotetext{
${ }^{29}$ Charles Krauthammer (2005), The Truth about Torture, It's time to be honest about doing terrible things, in The Weekly Standard, Volume 011, Issue 12, http://www.weeklystandard.com/Content/Public/Articles/000/000/006/400rhqav.asp?pg=1.
} 


\title{
References
}

Page | 16

\author{
Allhoff, Fritz (2005), A Defense of Torture: Separation of Cases, Ticking Time-bombs and Moral \\ Justification, in International Journal of Applied Philosophy, 19:2 \\ Bobbitt, Philip (2008), Terror and Consent: The Wars for the 21st Century, Allen Lane, London \\ Brecher, Bob (2007), Torture and the Ticking Bomb, Blackwell Publishing, Oxford \\ Carter, Phillip (2004), The Road to Abu Ghraib, in Washington Monthly, November 2004 \\ Defusing the Ticking Bomb Scenario, paper by the Association for the Prevention of Torture, \\ (2007), http://www.apt.ch/content/view/109/lang,en/
}

Dershowitz, Alan (2002), Why Terrorism Works, Yale University Press, New Haven \& London

Evans, Rebecca (2007), The Ethics of Torture, in Human Rights \& Human Welfare, Vol. 7

Krauthammer, Charles (2005), The Truth about Torture, It's time to be honest about doing terrible things, in The Weekly Standard, Volume 011, Issue 12,

http://www.weeklystandard.com/Content/Public/Articles/000/000/006/400rhqav.asp?pg=1

Lamb, Antony (2008), Review of Brecher, Bob (2007), Torture and the Ticking Bomb, Blackwell Publishing, Oxford, in Philosophical Frontiers, Vol. 3, Issue 2

Luban, David (2005), Liberalism, Torture, and the Ticking Bomb, in Virginia Law Review, Vol. 91, http://www.virginialawreview.org/content/pdfs/91/1425.pdf

Miller, David (1984), The Use and Abuse of Political Violence, in Political Studies, 32, 401

Slackman, Michael (2004), What's Wrong With Torturing A Qaeda Higher-Up?, in The New York Times, Sunday, May 16, 2004

Sung, Chanterelle, Torturing the Ticking Bomb Terrorist: An Analysis of Judicially Sanctioned Torture in the Context of Terrorism, http://bc.edu/schools/law/lawreviews/meta-

elements/journals/bctwj/23_1/05_TXT.htm

Waldron, Jeremy (2011), What Are Moral Absolutes Like, Lecture presented at the Annual Lecture for the Harvard Philosophy Club, Cambridge, Massachusetts, April 2011,

http://papers.ssrn.com/sol3/papers.cfm?abstract_id=1906850

Waldron, Jeremy (2010), Torture, Terror and Trade-offs: Philosophy for the White House, Oxford University Press 